\title{
Technology in the Montessori Classroom: Teachers' Beliefs and Technology Use
}

\author{
Sara J. Jones \\ University of Houston \\ Keywords: Montessori, technology, elementary, teacher beliefs
}

\begin{abstract}
As technology becomes ubiquitous in society, there is increasing momentum to incorporate it into education. Montessori education is not immune to this push for technology integration. This qualitative study investigates four Upper Elementary Montessori teachers' attitudes toward technology and technology integration in a public school setting. Interviews and observations were used to understand the teachers' thoughts and actions regarding technology in the classroom. Both the school context and teacher background played important roles in teachers' beliefs and actions. Teachers in this study expressed positive views of technology in general, exhibiting high technology efficacy and valuing the development of technology skills in their students. However, all four teachers struggled to include instructional technology in ways that are consistent with a Montessori paradigm. Although individual student use of adaptive tutoring software was the most common use of technology, the teachers varied greatly in both the amount of student time spent on computers and the roles that technology played in their classrooms.
\end{abstract}

\section{Introduction}

Recently, there has been a call for technology integration in schools that focuses on student use of technological tools in constructivist and socioconstructivist ways (ISTE, 2016; Partnership for 21st Century Learning, 2009; U.S. Department of Education, 2017). This technology use is being pushed not only in traditional public schools, but also in Montessori classrooms. In line with this movement, this research defines effective technology integration as teacher and student use of computer technology in constructivist and socioconstructivist ways to support the learning of core subject-area content (Read, Jones, Hughes, \& Gonzales-Dholakia, 2011).

\section{Technology in Schools}

In 2009, a U.S. national survey found that $97 \%$ of teachers had at least one computer in their classrooms, and 54\% were able to bring additional computers into their classrooms for technology-focused lessons (Gray, Thomas, Lewis, \& Tice, 2009). Despite this access to computers, only $40 \%$ of these teachers reported that their students often used technology during instructional time (Gray et al., 2009). Researchers have begun to view student use as a better measure for technology integration rather than simply counting computers in a classroom (Gray et al., 2009; Russell, Bebell, O’Dwyer, \& O’Connor, 2003). Eteokleous (2008) found two categories of student use of technology: traditional and transformative. The traditional view of technology integration is characterized as "learning about computers" and "learning from computers” (Eteokleous, 2008, p. 673). Learning about computers includes activities directed at increasing 
students' computer skills, while learning from computers refers to computer-assisted learning and drill and practice programs designed to teach students core subject matter. Transformative technology integration is a shift to "learning with computers" (Eteokleous, 2008, p. 673). In this approach, students use technology to create new meaning in constructivist or socioconstructivist ways. The creation of YouTube presentations is one example of this socioconstructivist approach because the students use technology to articulate their own understanding of a topic and present it to others.

Ferdig (2006) cautioned that research should include both the context and purpose of the innovation when judging technology integration. From this perspective, teachers' knowledge, views of technology, and teaching objectives are key to understanding if and when technology integration is appropriate. Ferdig (2006) proposed technological pedagogical content knowledge as a way to assess a teacher's decisionmaking regarding technology integration.

\section{Technological Pedagogical Content Knowledge}

Mishra and Koehler (2006) developed the concept of technological pedagogical content knowledge (TPACK) to emphasize the importance of teachers having an integrated understanding of how technology, content, and pedagogical methods work together to increase learning within their particular content discipline (Figure 1). The TPACK framework is structured after Shulman's (1986) idea of pedagogical content knowledge which asserts that, to be effective, teachers must have more than simply a knowledge of their content area and a separate understanding of pedagogy; they must also be aware of how to use pedagogy to support the teaching and learning of specific content knowledge. In the same way, TPACK represents the intersections among the three major knowledge domains of technology, pedagogy, and content, creating seven knowledge domains: content knowledge (CK), pedagogical knowledge (PK), technological knowledge (TK), pedagogical content knowledge (PCK), technological content knowledge (TCK), technological pedagogical knowledge (TPK), and

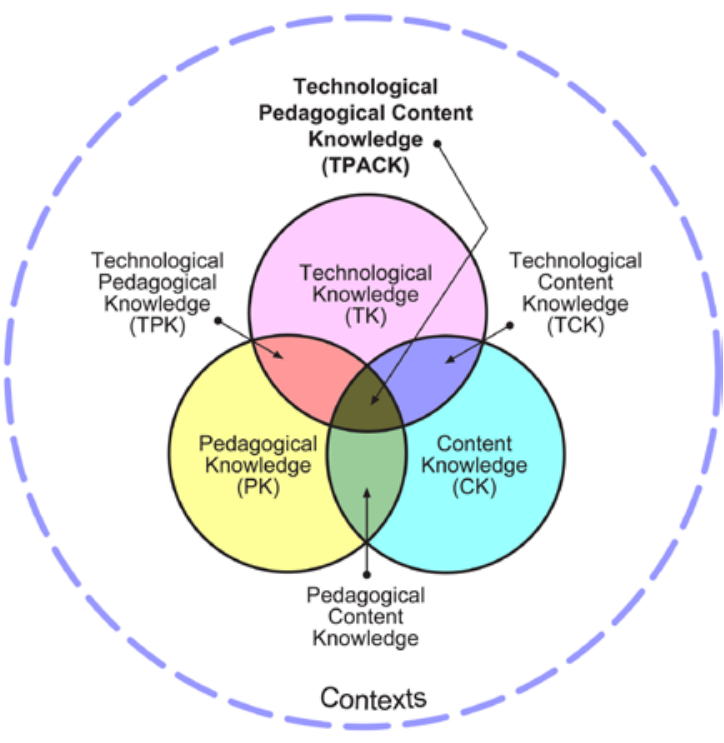

Figure 1. Technological pedagogical content knowledge. Reproduced by permission of the publisher, (C) 2012 by tpack.org

TPACK (Mishra \& Koehler, 2006). TPACK forms the core of the framework, and knowledge in this domain involves recognizing how technological tools, subject matter, and pedagogical techniques can work to augment or hinder one another. According to the model, teachers use technology most effectively when they are able to simultaneously consider the content, pedagogy, and functions and uses of various technologies (Niess, 2005).

The TPACK framework is typically measured and described as a knowledge framework (Archambault \& Crippen, 2009; Mishra \& Koehler, 2006; Schmidt et al., 2009). However, because knowledge and beliefs are very intertwined (Kagan, 1992), it is difficult to understand teachers' TPACK without considering their beliefs about pedagogy, technology, and the subject matter they teach. Hervey (2011) found that teachers' attitudes about technology as an instructional tool greatly influenced the ways they used technology in their classes. Experienced teachers who had a well-developed PCK had difficulty integrating technology that conflicted with those beliefs and preferences. Ertmer (2005) proposed that, since teachers' initial experiences both with teaching and with technology shape their future actions, their "personal theories and beliefs are rarely sufficiently revised and, thus over time, become deeply personal, highly engrained, and resistant to change” (p. 30). Because PK and beliefs influence teachers' technology 
adoption (Ertmer, 2005; Teo \& Zhou, 2016), teachers who hold strong Montessori beliefs will most likely integrate technology in ways that align with the Montessori paradigm, and novice Montessori teachers may need more support than experienced teachers to include technology in constructivist and socioconstructivist ways.

\section{Montessori Education}

Maria Montessori considered children to be whole beings, capable of learning without much interference from adults (Montessori, 1912). Under the Montessori paradigm, learning is guided by the child rather than the teacher.

Education is a natural process spontaneously carried out by the human individual, and is acquired not by listening to words but by experiences upon the environment. The task of the teacher becomes that of preparing a series of motives of cultural activity, spread over a specially prepared environment, and then refraining from obtrusive interference. (Montessori, as cited in Faryardi, 2007, p. 3)

Although Dr. Montessori did not explicitly instruct teachers to take a constructivist approach to learning, Montessori techniques and materials do provide opportunities for students to interact with and construct meaning from their environment in a way that is consistent with this theoretical paradigm (Elkind, 2003; Ültanir, 2012).

Dr. Montessori also felt that "the child should love everything he learns, for his mental and emotional growths are linked” (1989, p. 17). For this to occur, she suggested that students be allowed to direct the activities they wish to complete at any given time (Faryardi, 2007). Although autonomy is supported, a sense of personal and social responsibility for learning is also instilled in children in a Montessori classroom (Faryardi, 2007). In this way, Montessori curriculum overlaps with socioconstructivism in emphasizing social support in multiage classrooms. These classes are frequently referred to houses and, as evident in family-style meals and peer learning, function as an interdependent learning community.

In the traditional Montessori school, the only materials available to students were those created by Dr. Montessori herself (Lillard, 2008). These hands-on learning activities and puzzles were the basis for the entire curriculum. However, it can be difficult for American public schools to align completely with an authentic Montessori paradigm, and many schools adapt and augment the materials created by Dr. Montessori (Lillard, 2008; Monson, 2006). Although some members of the Montessori community feel that these changes may hurt the integrity of the paradigm (Lillard, 2008), others argue that new materials and new technologies are needed because the original materials may not authentically reflect contemporary society (Hubbell, 2006). Because technology is now integrated into our daily lives, some researchers and educators are pushing for the integration of technology in Montessori classes as a way to provide more authentic and meaningful learning experiences (Hubbell, 2006; Love \& Sikorski, 2000). Despite this push, little research has studied the actual integration of technology in the Montessori classroom.

\section{Methods}

\section{Statement of Problem}

This study seeks to qualitatively assess Montessori teachers' belief about and uses of technology through two research questions. (a) What are Montessori teachers' beliefs about the use of technology in the classroom? and (b) Is TPACK demonstrated in the technology Montessori teachers choose to use in Lower Elementary school classrooms? 


\section{Site of Study}

Openwood ${ }^{1}$ Elementary School is one of 170 elementary schools in a large urban school district in the southwestern United States. Openwood serves about 600 children from pre-kindergarten through sixth grade. During the year of this study, 2011-2012, the student population was 65\% Hispanic, 24\% White, 7\% Black, and 1\% Asian or Pacific Islander. Another 4\% of students reported multiple ethnicities, and 56\% of students qualified for free or reduced lunch. Thirty-seven teachers, with an average of 13 years of experience, worked at Openwood in 2011-2012. Teachers at the school taught in one of two programs: a traditional public school or a Montessori charter. Under the traditional system, the teachers follow the district curriculum for one or two grade levels. All Montessori classes are self-contained, multilevel classes. In the past, the school had consistently met its annual yearly progress, but in 2010-2011, the school did not meet the district's annual yearly progress standards.

Montessori charter. Openwood's Montessori charter program serves students from across the school district, beginning at age 3. Priority is given to students in the neighborhood school zone, and a lottery is used to fill the remaining seats. Pre-kindergarten children are charged a fee to attend but can apply for financial aid from community partners.

The school received a grant to expand the Montessori program to a whole-campus charter over 3 years. At the end of the 2009-2010 school year, all teachers were given the opportunity to begin Montessori training. The school district paid for the Montessori training fees for teachers who committed to teach in the district for 3 years. In 2011-2012, the school had 20 Montessori classrooms and only nine traditional curriculum classrooms. Openwood's Montessori program is an Americanized Montessori program, meaning that the teachers can be flexible with the Montessori curriculum to better prepare students for state and national grade-level testing. This flexibility includes incorporating materials that may not be found in traditional Montessori classrooms.

Technology resources. Openwood Elementary School has one computer lab with 27 computers. In the 2011-2012 academic year, a technology specialist was hired to teach ancillary classes in the computer lab. Each classroom also contained three to five computers and a document camera.

During the 2010-2011 school year, the principal began a 2-year technology-integration leadershiptraining program. Through an evaluation in conjunction with that training program, Openwood earned a novice-level rating in technology integration. Beyond the principal's emphasis on technology, the ParentTeacher Organization dedicated its 2011-2012 fundraising efforts to the purchase of more technology resources.

\section{Participants}

All kindergarten through sixth-grade teachers were invited to participate in technology-focused professional development with their planning teams. The planning teams were determined according to the members' scheduled planning periods and consisted of three to five teachers teaching similar grade levels. This study focuses on one team, composed of four Lower Elementary Montessori teachers.

\section{Analysis}

I used case studies (Corbin \& Strauss, 2008; Yin, 2009) to understand the teachers’ beliefs and uses of technology in the Montessori classroom. For the purpose of triangulation, I used multiple data sources throughout the semester. Data sources and their analyses are discussed below.

\footnotetext{
${ }^{1}$ All school and teacher names are pseudonyms.
} 


\section{Data Sources}

Interview transcripts. All of the teachers were interviewed at least once during the semester. Two of the teachers agreed to interviews at both the beginning and the end of the semester, totaling six interview transcripts. All interviews were transcribed and coded using a combination of open coding and preestablished TPACK codes (Hughes, Guion, Bruce, Horton, \& Prescott, 2011). A peer reviewer coded samples of the transcripts to verify the a priori and emerging themes and to discuss problem areas in the coding.

Lesson plans. Lesson plans for the entire semester were requested from the teachers, but only one teacher submitted a sample of lesson plans. Lesson plans that included technology were reviewed using the TPACK rubric (Harris et al., 2010).

Class observations. Ten classroom observations were conducted. Field notes were coded using the TPACK rubric (Harris et al., 2010).

Group meeting transcripts and field notes. I recorded and observed all eight teacher meetings, writing field notes about the number of attendees, the tone of the meeting, and the topics discussed.

Teacher cases. A teacher case was constructed for each consenting teacher. This profile included a summary analysis from their interviews and lesson plans. Other group members' perceptions of the teacher were also included in the teacher profiles when applicable.

\section{Results}

\section{Montessori Lower Elementary Team}

The Montessori Lower Elementary team (see Table 1) consisted of four classroom teachers: Kenneth, Lance, Marianne, and Nathan ${ }^{2}$. The following section describes each teacher's philosophies of teaching and of technology use in the Montessori classroom.

\section{Teacher Cases}

Marianne. Marianne had 14 years of teaching experience, two in a high school computer lab and 12 in a Montessori classroom. Because she had the most experience and had been at Openwood the longest, Marianne was the team leader. In her teaching, Marianne focused on her students and their individual learning. She said that it was her job to

give them what they need and then teach them what they need to know in order to grow up to be whatever they want to be in life. They need this foundation. This is very important, even though it's only an elementary school. If you don't do well now, it builds up, and I feel it's very important for me as a teacher to be aware of that and to have that in mind all the time. (Interview 1)

Marianne used a combination of individual, small-group, and whole-class lessons to facilitate her students' learning. Students were also expected to take responsibility for their learning and spent significant time working on individual Montessori materials.

Marianne majored in computer science and had worked in the computer software business. She stated that she was very comfortable teaching technology skills in the high school computer lab, but she did not have time to teach those skills in the elementary class. Marianne knew that technology skills were crucial for her students: "Technology is actually very important because nowadays everything is based on technology, and we as adults are asked to do it [use technology] in order to be competitive” (Interview 1).

\footnotetext{
${ }^{2}$ All names are pseudonyms.
} 
Table 1

Participants and Technology Used in Classrooms

\begin{tabular}{|c|c|c|c|c|c|c|c|c|c|c|}
\hline \multirow[b]{2}{*}{ Teacher } & \multirow[b]{2}{*}{$\begin{array}{l}\text { Teaching } \\
\text { experience } \\
\text { (years) }\end{array}$} & \multirow[b]{2}{*}{$\begin{array}{c}\text { Classroom } \\
\text { computers } \\
(n)\end{array}$} & \multicolumn{8}{|c|}{ Technology used in classroom } \\
\hline & & & Pro & ESW & EW & $\mathrm{R}$ & Word & PP & B & A \\
\hline Marianne & 14 & 3 & & $x$ & & $x$ & $x$ & $x$ & $x$ & \\
\hline Kenneth & 8 & 6 & $x$ & & & & & & & \\
\hline Lance & 2 & * & & $x$ & & $x$ & & & & \\
\hline Nathan & 15 & 4 & & $x$ & $x$ & & & & & $x$ \\
\hline
\end{tabular}

Note. ${ }^{*}=$ unknown; Pro = Projector or Elmo; ESW = educational software; EW = educational website; $\mathrm{R}=$ computer used for research; Word = Microsoft Word; PP = Microsoft PowerPoint; $\mathrm{B}=$ blogs; $\mathrm{A}=$ assessment software; $\times$ = in use.

She wanted her students to learn basic computer skills like Microsoft Word and PowerPoint. On the other hand, she remarked that the "true Montessori" curriculum did not include technology. She felt that the principal was trying to incorporate technology at Openwood only because it was a public school and the district was emphasizing technology.

Marianne had only one teacher computer and two student computers in her classroom, fewer than most teachers in the school had. She had been offered more computers but did not have space for them in her classroom. Students mostly used educational software programs that tracked individual student progress in math and reading. Some of her students also had started to use blogs to publish their research projects; this blog use was initiated by a student, not by Marianne. The student had asked to use the blogging tool that she used at home. Marianne liked the idea and said that other students wanted to learn as well. Marianne allowed the student to teach her classmates how to create a blog (Interview 2).

Because Marianne had 12 years of teaching experience in a Lower Elementary Montessori classroom, other teachers often called her the expert and asked her for help and suggestions during team meetings. However, Marianne did not offer more suggestions than other teachers did.

Kenneth. Kenneth had taught for 8 years in a Montessori classroom, but he also emphasized life experiences other than teaching and working with children. He felt that

teaching to me is more of an avocation, not a vocation. It's a hobby. If I had millions of dollars, I'd do this for free. I would be a teacher just because it's so pleasurable. It's so wonderful to see the light go on. (Interview 1)

Kenneth's previous teaching experience had been in an Early Childhood Montessori classroom (pre-K through kindergarten), and the study year was his first as a Lower Elementary Montessori teacher (first through third grades).

In terms of teaching, Kenneth was adamant that Dr. Montessori was brilliant and that her curriculum was the most beneficial for student learning. In his pre-interview he stated, "Public education is the illness; Montessori is the cure" and explained why.

A lot of really dedicated people have tried to discover a way to make... educating children work, and Montessori just already does that. So the joy of being a Montessori teacher is 
so profound. You get to have the children for three years. You have a learning society. (Interview 1)

From his perspective, public education had developed during the industrial revolution to train people using one set method for every student, much like a factory, and did not effectively address individual differences. He felt that addressing these differences was a strength of Montessori education. In his interviews, he also discussed recent research on learning and brain functioning to emphasize how many of Dr. Montessori's theories were being confirmed by brain studies today.

Kenneth did not see technology in opposition to a Montessori curriculum, but rather as an important complement to his curriculum. He speculated that if Dr. Montessori were living today, she would have invented a technology-rich robotic classroom. He saw technology as a way to differentiate and individualize instruction for his students. Kenneth shared ideas about the ways that face recognition, temperature sensors, and tracking software could be used to create a classroom where data collection was ongoing, and computers with artificial intelligence provided immediate information to help teachers target student misconceptions. He felt that educational technologies were neglected.

I cannot tell you how frustrated I am that there is software to sell people things, there is software to track stock markets, and you can sign on and get on a website and have all this software and all this hardware at work on you. I mean there's more technology in a cell phone ... it knows where the nearest place is to get an ice cream soda or it'd give you a choice of three. And it's just phenomenal that the education of our future generations is not worthy of that kind of investment. (Interview 1)

In his classroom, Kenneth used computer software that tracked individual student progress, but his technology use was limited by school resources. In regard to technology in his class, he remarked, "I love it. Give me more. Give me a million-dollar grant. You'll see some action here” (Interview 1). In addition to the software programs provided by the school, Kenneth used Microsoft PowerPoint to make electronic flashcards for his students to learn vocabulary words. The computers in his classroom served as a workstation. Students could use computer programs for their math or reading lessons but were not required to use the computers. This element of choice resulted in some students spending lots of time on the computers, while others rarely chose to use technology.

Kenneth also had a projector in his classroom but struggled with how to use it effectively. In his interview, he described wanting to use his projector in a more student-focused way.

I would do more with my projector, but the priority is the individualized learning of every child and the projector is a kind of a whole-group event. So I've yet to bridge the gap between small-group and individualized learning with the technology I have available. Once the projector is on, everybody's brain just shuts off and they all stare at whatever I'm doing. But I'm planning on using [the digital projector] with a new terrarium .... I want to have that camera focused on it, and it will be running full time. Students will be able to do their observation and zoom in and out. (Interview 1)

The terrarium and projector were not set up during the time I completed my observations.

Kenneth discussed how difficult it was to get the technology resources that he wanted in his classroom. During the observations, he had six computers, but he mentioned that he had begged for these computers. With his computers, he was planning to have the students improve their writing and spelling by teaching them to type journals using Microsoft Word and make informed decisions about grammar and spelling using the spell-check function.

Kenneth also felt the pressure to improve his students' scores on the mandated state and district standardized tests. Kenneth did not feel prepared for the new district and state testing and was having a difficult time learning to merge the Lower Elementary curriculum with the standardized assessments. He found this especially difficult because he was new to teaching first through third grades and was still struggling to learn the curriculum and expectations for those students. He explained that there was some 
contention among the Montessori teachers about which textbooks and software, if any, were appropriate in the Montessori classroom. He said that he had tried to enlist other Montessori teachers to help create testpreparation materials that aligned with the Montessori curriculum, but no one was willing to take the extra time to do so. His response was to use school-provided materials to supplement his Montessori materials. Despite his strong beliefs in the Montessori curriculum, Kenneth had a practical outlook on testing and its importance for his class. Kenneth felt that if Montessori students did not perform well on standardized tests, the program would be cut. He wanted the "Montessori experts," (i.e., teachers with the most Montessori experience) to get together with the newer Montessori teachers to create materials that would bridge the gap between the standardized tests and the Montessori curriculum.

Lance. Lance consented to only one interview and the recording of his involvement in the weekly group meetings, so no observations were collected. He was in only his second year of teaching and his first year in a Montessori classroom. He did have some previous experience as an aide in a Montessori classroom but was having a difficult time managing the new curriculum, a multiage class, and the standardized tests. His interview took place toward the end of the semester. Several times during the interview, he mentioned being "overwhelmed."

He may have felt overwhelmed by the pressure he put on himself as a teacher. He viewed his role as a teacher broadly: Lance felt responsible not only for his students' content-area learning, but also for their emotional well-being. While other teachers tended to describe themselves as facilitators, Lance classified himself as a "classroom manager, psychologist, and life coach" (Interview). He set up routines and procedures "to motivate the students to do their best" with the goal of "[helping] these young children to feel okay about themselves" (Interview). This need to be everything for his students, paired with his inexperience, caused him more stress than it did other teachers at the school.

Further, Lance had to be absent from the classroom for several days for required professional development. Lance also described the professional development as "overwhelming" and was not sure how to implement the information or find the time to do so.

I don't have a lot of time outside of the classroom, and that's really what, to do this successfully, that's really what you have to do. You really have to spend a lot of time planning out all these little details. There's a lot of detail, a lot of details in this job. (Interview)

Teaching was Lance's second career. He had switched to teaching from technology, as a way to slow down, but was not finding teaching to be what he had expected.

Another source of Lance's stress was balancing the Montessori curriculum in a public-school setting with other demands, which was especially hard for him as a first-year Montessori teacher.

To have three different grade levels in here and to have all this focus on this new big [state-standardized] test for my third graders and all these other programs going on, it'sand then for me, and like several other people here going through their internship year in Montessori, where you're really trying to follow exactly what we just came out of and trained, but kind of having these different camps pulling and pushing with what's important and what are we doing. (Interview)

The growth of Openwood's Montessori program meant that the school's test scores and ratings were more affected by the Montessori students' scores than in previous years. Unfortunately, the Montessori students did not perform well on benchmark testing. Both the principal and her district supervisor were concerned and placed additional pressure on the Montessori teachers to raise student test scores.

Coming from a technology background, Lance was comfortable using technology and stated that it was important for his students to be able to use technology. However, he did not think that much of the educational software provided by the school was consistent with Montessori education. His students were able to use computers during their Montessori work time only as a tool for research or for one reading 
intervention program. Students were allowed to use other educational software only after they had completed all of their daily Montessori work.

Lance thought the school was moving in the right direction regarding technology use but felt the implementation was still lacking in some areas. While most teachers were asking for more computers in their classrooms, Lance saw a greater need for human support for technology implementation on campus.

We just really need somebody who can really drive all that, and so to have a technology person who's also spending $90 \%$ of their time teaching ancillary classes, it's going to be very challenging for the teachers to spend the time and figure out what to do to get certain pieces of software up and running, and set up systems, and solve problems, and we have issues, and then you have to take time to call the help desk, and so to coordinate all that for teachers is very challenging. (Interview)

Beyond hardware and human support, school technology policies also determined the programs Lance used in his class. He, like other teachers at the school, used programs that were licensed by the school or district.

Email was another way Lance used technology. He complained that he received too much email and again described it as "overwhelming."

I could spend every [weekly team] meeting sitting at my computer going through all the emails I get, and trying to process which ones I have to deal with, which ones can wait. I mean, I could have a to-do list like this, and it's just kind of gotten to a point now where if somebody's not barking up my tree, I'm just not worrying about it. That's kind of unfortunate that it gets to that point, but it's just too much. There's no filtering ... so, we're just spread too thin. (Interview)

Like professional development, email was another form of information overload for Lance.

Nathan. Nathan had 15 years of experience in education. He had taught at both the elementary and high school levels. He also had served 2 years as a high school assistant principal and 2 years as head principal. To get out of the high school environment, Nathan took an assistant principal position at Openwood. During the summer of 2010, the assistant principal position was eliminated, and Nathan decided to go back into the classroom as a Montessori teacher. Openwood was his first experience with a Montessori curriculum, and he liked that the curriculum encouraged critical thinking. His class was one of two bilingual Lower Elementary Montessori classes in the school and the only bilingual class in this team. Nathan consented to the interviews, class observations, and participation in weekly team meetings. His classroom was observed, and team meetings were recorded. However, scheduling conflicts limited him to only one interview, near the end of the semester.

Nathan's high school experiences influenced how he viewed his role as a teacher. He believed that his students needed to enter middle school "two grade levels ahead in content mastery," and it was his goal to push them in that direction. He felt that if students were ahead of the curriculum when they entered middle school, they were less likely to drop out in high school. He wanted his students to be critical thinkers and did not agree with a top-down approach to education. "I want to make a vision for the child so he can think outside the box down the road, and that's what I want” (Interview). While Nathan saw critical thinking as a strength of the Montessori Method, he also mentioned deficits in the system. He had observed teachers - in his school and in other schools_-using reading materials that were inappropriate or too easy. He supplemented the traditional Montessori curriculum with more guided-reading lessons and writing workshops, techniques he had learned during his master's program.

As a bilingual teacher, he also stressed English language skills. He asserted that his third-grade students were capable of taking the standardized tests in English and wished they were allowed to do so. He felt that practicing for the test in Spanish—when they would test in English the following year-was counterproductive. 
Nathan enjoyed working with students whom others found difficult. He used positive encouragement and high expectations to push struggling students to succeed. He was strict with these students but always respectful. He also said that he "never gave up" on these students.

I never yell at them. I never say they're stupid. Nothing. I just keep working with them and keep working with them. Sometimes I have to calm them so they won't hurt anybody.... I'm firm with them. They understand that. They can't get out. I keep them there for five minutes and I’m like, “Okay. Are you ready to learn now?” (Interview)

Because these troubled students were so difficult for other teachers, Nathan found it rewarding to be able to help them succeed.

Regarding technology, Nathan stated that he "tried to use it as much as [he could]" and that he used it "quite a bit." Nathan viewed technology as a "resource" but said that it was "never going to replace the instructor" (Interview). He thought a teacher was needed to guide students and to assess their learning. The teacher could then use technology to help students improve specific skills.

I use it as a resource, but I teach to listen, do hands-on, do questions hands-on, and then I'll put them on the computer for them to practice. And then they have to write, what have you, and then they get it. Then they test it. (Interview)

Nathan used online resources to supplement other classroom activities. However, he was not satisfied with the programs purchased by the school and district. He used several free, online programs and even personally paid for the licensing fees for one program. After benchmark test scores proved low, Nathan decided to use the district's test-bank software to create common assessments for his team, appearing comfortable using that program. After producing the first test, he wanted to teach other members of his team how to make them so they could all share that responsibility. He believed other teachers would be more likely to use the tests if they were involved in the design. He said, "You can give them information all day long, and they're not going to use it. They won't use it unless they're involved in the planning, like they're planning three weeks ahead and all that with you" (Interview). Nathan reiterated that you cannot force information on teachers - they must either ask for the information or be repeatedly included in the planning in some way. He also demonstrated this belief in his interactions with his team.

\section{Technology Beliefs, Knowledge, and Integration}

Several patterns emerged in how Openwood Montessori teachers approached technology, which can be grouped into two main themes: positive attitudes toward technology and TPACK-based decisions and technology use.

Attitudes toward technology. All teachers exhibited generally positive attitudes toward technology. They said that technology skills were important in today's society and felt that technology could be used to supplement other forms of instruction, despite some debate about the fidelity of technology integration in the Montessori curriculum. Most agreed that additional technology resources (e.g., computers) were needed.

Negative attitudes about technology focused on the difficulty of maintaining a balance between human interaction and computer time. Teachers were not opposed to technology use but felt it was important to not let it replace all human interaction between teachers and students. They also debated the types of technology and programs that align with, rather than compete with, Montessori philosophy. All teachers dealt with this struggle in their own way.

TPACK and technology use. The teachers at Openwood had technology experience and knowledge but did not use technology in transformative ways. Both Marianne and Lance had computer backgrounds, and all other teachers said they were at least moderately comfortable with technology. Students also were observed using individual drill-and-practice software. A few teachers mentioned using 
technology in more student-directed ways, such as blogs and student-created PowerPoint presentations, but these uses were not observed.

While the teachers were not using much transformative technology, they demonstrated some TPACK reasoning when describing why they chose to use various technologies. Teachers demonstrated much technological pedagogical knowledge, often citing the ability to differentiate instruction and motivate student learning by integrating technology into their teaching. The teachers used individualized and adaptive software because it allowed them to track student progress and differentiate instruction for their students. Some of these programs were aligned with district and state content standards and the mandated tests, showing technological content knowledge. The school held licenses for several educational programs, but the teachers did not use all of these programs. Each of the teachers had preferences for certain programs over others, and they were able to articulate clearly which software they liked or disliked and why. These reasons included ease of use, but focused mainly on the rigor of the activities or alignment with the teachers' beliefs about student learning.

Finally, most of the teachers were capable of generating transformative ways to use technology (e.g., creating blogs and class websites), but they chose not to do so because of time constraints, lack of resources, or a low perceived value of these activities in a Montessori classroom.

\section{Conclusion}

Regardless of teaching experience, all teachers at Openwood Elementary School reported feeling confident with technology. Previous research had found that novice teachers reported feeling more confident in their general technology use when compared to their technology use in the classroom (Russell et al., 2003). This dissonance could be due to a lack of content or pedagogical knowledge, although most teachers used some TPACK in their technology choices. While they indicated that software that allowed for self-pacing and differentiation was appropriate to a Montessori paradigm - clearly acknowledging the technology affordances, the subject matter content, and the type of pedagogy that they wanted to usethese decisions did not lead to transformative technology use. It is possible that the teachers were unable to use technology in transformative ways, not because of a lack of technology knowledge, but rather a lack of constructivist or socioconstructivist pedagogical knowledge or access to or knowledge about technology tools that are more interactive. All teachers focused on technology's capacity for individualized pacing, but they rarely capitalized on the affordances of creating and sharing information.

Previous research found that teachers' beliefs about teaching influence how they use technology in the classroom (Ertmer, 2005; Hervey, 2011; Niess, 2005; Ravitz, Becker, \& Wong, 2000; Sang, Valcke, van Braak, \& Tondeur, 2010). The Montessori teachers in this study generally described their lessons in a constructivist manner, establishing an environment that encouraged individual student exploration and learning. They also spoke frequently of building critical thinking skills in their students and using computers for student-driven research. However, the technology use, while self-paced, was often still didactic.

Even teachers with socioconstructivist teaching beliefs and practices may need outside expertise to be able to use technology in transformative ways. Hughes et al. (2011) proposed a framework for action (FFA) that involves outside experts who are familiar with how teachers learn and change their practices, as well as with TPACK. In the FFA, these experts intervene at various critical decision points during implementation of new technology. This intervention addresses Lance's concern that teachers could not be successful in integrating technology in sociocontructivist ways without additional personnel resources to focus on the technology.

Some teachers cited a lack of computers as the main reason for their limited technology use, which is consistent with previous research in the field (Gray et al., 2009). The teachers used computers mainly as a station at which a limited number of students could take turns working independently. Software decisions were generally influenced more by availability than by the quality or pedagogical relevance of the software to classroom content. Only Nathan used his supply budget to purchase licenses for a software program not readily available at the school. 


\section{Limitations}

This qualitative study is an initial look at how technology fits into a Montessori curriculum. The limited sample of teachers is not representative of the whole population of Montessori teachers. The sample was 75 percent male, which is an anomaly in the field of education. Moreover, all of the teachers claimed a high degree of comfort with technology, but many had a low degree of comfort with the Montessori paradigm, as they were in their first year teaching in that system.

Further, the definition of technology integration has shifted over the years. This study defines technology integration as the use of technology in constructivist and socioconstructivist ways to support learning in content areas (Read et al., 2011). The TPACK framework (Mishra \& Koehler, 2006) was used to investigate individual teachers' knowledge, beliefs, and reasoning as they integrated technology in their classrooms. Even within this framework, capturing and measuring an individual's thought processes can be complex. The teachers' reasoning and intentions were usually not obvious during observations, and teachers do not always act in accordance with their stated beliefs (Calderhead, 1996). Triangulation of several class observations, interview data, and group meetings was used to gather the fullest possible picture of these teachers' technology knowledge, beliefs, and use. An added challenge with measuring teachers' TPACK lies in the ambiguity of the framework itself. Graham (2011) argued that the overlapping TPACK categories lack parsimony and are therefore difficult to distinguish.

\section{Suggestions for Future Research and Practice}

If school and district administrators want teachers to use more transformative technology, they need to re-evaluate the hardware and software they provide to teachers. Although most schools have some computers and Internet access, the quality of those resources varies greatly. Teachers in this study still report lack of appropriate technology as a barrier to technology integration. The school in this study had a classroom set of laptops, but due to issues with Wi-Fi connectivity, they were used in a laboratory setting rather than used flexibly by classroom teachers. Without consistent Internet access, many of the affordances that allow for transformational learning with computers cannot be realized. Hughes et al. (2011) called for the use of more Web 2.0 tools (e.g., presentation software, blogs, YouTube) in schools. They proposed that "openness and social interaction inherent in Web 2.0 support learners in generating and refining their understandings, as they read, reflect, and create new content to share with others" (Hughes et al., 2011, p. 54). Much of this technology is limited or restricted in U.S. public schools due to legitimate privacy concerns, but these barriers need to be re-evaluated if we hope to move toward a more transformative use of technology in our schools, where students are not simply learning from technology but rather using technology to build, understand, and create new meaning and content. The latest National Education Technology Plan update also recommends that "states, districts, and postsecondary institutions should develop and implement learning resources that embody the flexibility and power of technology to create equitable and accessible learning ecosystems that make learning possible everywhere and all the time for all students” (U.S. Department of Education, 2017, p. 25). As more schools adopt 1-to-1 laptop or tablet policies and Bring Your Own Device programs, teachers and students can begin to capitalize on the new capabilities technology can offer. Teachers should use this ubiquitous access to technology to facilitate deeper learning using real-life applications (Johnson, Adams Becker, Estrada, \& Freeman, 2015).

Future research should also examine across multiple settings how Montessori teachers view technology. There was no strong consensus in this study about the degree and type of technology that should be included in a technology classroom. The Montessori community as a whole has not reached a consensus on this issue, and much work remains to understand if and when technology use can support Montessori ideals. The teachers in this study focused on individualized, adaptive tutoring programs rather than more constructivist technologies. The question still remains: Can technology integration truly exhibit the spirit of a Montessori classroom, or will it simply become the obtrusive interference? For the Montessori 
community to address this issue in an informed way, rigorous qualitative and quantitative research is needed to better understand the impact of technology on students’ motivation, learning, and development.

\section{AUTHOR INFORMATION}

Sara J. Jones is an assistant professor in Psychological, Health and Learning Sciences at the University of Houston and can be reached at sjjones3@uh.edu.

\section{References}

Archambault, L., \& Crippen, K. (2009). Examining TPACK among K-12 online distance educators in the United States. Contemporary Issues in Technology \& Teacher Education, 9(1). Retrieved from http://www.citejournal.org/volume-9/issue-1-09/general/examining-tpack-among-k-12-onlinedistance-educators-in-the-united-states/

Calderhead, J. (1996). Teachers: Beliefs and knowledge. In D. Berliner \& R. Calfee (Eds.), Handbook of Educational Psychology (pp. 709-725). New York: Macmillan Library Reference.

Corbin, J., \& Strauss, A. (2008). Basics of qualitative research: Techniques and procedures for developing grounded theory (3rd ed.). Thousand Oaks, CA: SAGE. https://doi.org/10.4135/9781452230153

Johnson, L., Adams Becker, S., Estrada, V., and Freeman, A. (2015). NMC Horizon report: 2015 K-12 edition. Austin, TX: The New Media Consortium. Retrieved from http://cdn.nmc.org/media/2015nmc-horizon-report-k12-EN.pdf

Elkind, D. (2003). Montessori and constructivism. Montessori Life, 15(1), $26-29$.

Ertmer, P. A. (2005). Teacher pedagogical beliefs: The final frontier in our quest for technology integration? Educational Technology Research and Development, 53(4), 25-39. doi:10.1007/BF02504683

Eteokleous, N. (2008). Evaluating computer technology integration in a centralized school system. Computers in Education Journal, 51, 669-686. https://doi.org/10.1016/j.compedu.2007.07.004

Faryardi, Q. (2007). The Montessori paradigm of learning: So what? Available from https://eric.ed.gov/?id=ED496081

Ferdig, R. E. (2006). Assessing technologies for teaching and learning: Understanding the importance of technological pedagogical content knowledge. British Journal of Educational Technology, 37, 749760. https://doi.org/10.1111/j.1467-8535.2006.00559.x

Graham, C. R. (2011). Theoretical considerations for undertaking technological pedagogical content knowledge (TPACK). Computers \& Education, 57, 1953-1960. https://doi.org/10.1016/j.compedu.2011.04.010

Gray, L., Thomas, N., Lewis, L., \& Tice, P. (2009). Teachers' use of educational technology in U. S. public schools: 2009 first look. (NCES 2010-040). Washington, DC: National Center for Educational Statistics, Institute of Educational Sciences, U. S. Department of Education. Retrieved from https://nces.ed.gov/pubs2010/2010040.pdf

Harris, J. B., Hofer, M. J., Schmidt, D. A., Blanchard, M. R., Young, C. Y., Grandgenett, N. F., \& van Olphen, M. (2010). "Grounded” technology integration: Instructional planning using curriculumbased activity type taxonomies. Journal of Technology and Teacher Education, 18, 573-605. Available from http://www.editlib.org/p/30418

Hervey, L. G. (2011). Between the notion and the act: Veteran teachers' TPACK and practice in 1:1 settings [Doctoral dissertation]. Available from ProQuest. (UMI No. 3463705).

Hubbell, E. R. (2006). Authenticity and technology in Montessori education. Montessori Life, 18(2), 1620. Available from EBSCO Host http://connection.ebscohost.com/c/articles/20982979/authenticity-technology-montessorieducation

Hughes, J. E., Guion, J. M., Bruce, K. A., Horton, L. R., \& Prescott, A. (2011). A framework for action: Intervening to increase adoption of transformative web 2.0 learning resources. Educational Technology, 51(2), 53-61. 
ISTE. (2016). National educational technology standards for students (NETS-S). Retrieved from https://www.iste.org/standards/standards/for-students-2016\#startstandards

Kagan, D. M. (1992). Implications of research on teacher belief. Educational Psychologist, 27(1), 65-90. https://doi.org/10.1207/s15326985ep2701 6

Lillard, A. (2008). How important are the Montessori materials? Montessori Life, 20(4), 20-25.

Love, A. \& Sikorski, P. (2000). Integrating technology in a Montessori classroom. Report No. ED441600. Retrieved from ERIC http://files.eric.ed.gov/fulltext/ED441600.pdf

Mishra, P., \& Koehler, M. J. (2006). Technological pedagogical content knowledge: A framework for teacher knowledge. Teachers College Record, 108, 1017-1054. https://doi.org/10.1111/j.14679620.2006.00684.x

Montessori, M. (1989). To educate the human potential. Oxford, England: Clio Press.

Montessori, M. (1912). The Montessori Method. New York, NY: Frederick Stokes Co.

Monson, M. (2006). Reconstructing Montessori: On being an authentic Montessori school. Montessori Life, 18(2), 36-43.

Niess, M. L. (2005). Preparing teachers to teach science and mathematics with technology: Developing a technology pedagogical content knowledge. Teachers and Teacher Education, 21, 509-523. https://doi.org/10.1016/j.tate.2005.03.006

Partnership for 21st Century Learning. (2009). P21 framework definitions. Retrieved from http://www.p21.org/storage/documents/P21_Framework_Definitions.pdf

Ravitz, J. L., Becker, H. J, \& Wong, Y. T. (2000). Constructivist-compatible beliefs and practices among U.S. teachers. Teaching, learning, and computing: 1998 National Survey (Report \#4). Center for Research on Information Technology and Organizations, University of California, Irvine and University of Minnesota. Retrieved from ERIC http://files.eric.ed.gov/fulltext/ED445657.pdf

Read, M. F., Jones, S. J., Hughes, J. E., \& Gonzales-Dholakia, G. (2011, April). An ecological case study of two middle schools' technology integration. Paper presented at the annual meeting of the American Educational Research Association, New Orleans, LA.

Russell, M., Bebell, D., O’Dwyer, L., \& O’Connor, K. (2003). Examining teacher technology use: Implications for preservice and inservice teacher preparation. Journal of Teacher Education, 54, 297-310. https://doi.org/10.1177/0022487103255985

Sang, G., Valcke, M., van Braak, J., \& Tondeur, J. (2010). Student teachers' thinking processes and ICT integration: Predictors of prospective teaching behaviors with educational technology. Computers \& Education, 54, 103-112. https://doi.org/10.1016/j.compedu.2009.07.010

Schmidt, D. A., Baran, E., Thompson, A. D., Mishra, P., Koehler, M. J., \& Shin, T. S. (2009). Technological pedagogical content knowledge (TPACK): The development and validation of an assessment instrument for preservice teachers. Journal of Research on Technology in Education, 42(2), 123149. https://doi.org/10.1080/15391523.2009.10782544

Shulman, S. S. (1986). Those who understand: Knowledge growth in teaching. Educational Researcher, 15(2), 4-14. https://doi.org/10.3102/0013189x015002004

Teo, T., \& Zhou, M. (2016). The influence of teachers' conceptions of teaching and learning on their technology acceptance. Interactive Learning Environments. http://dx.doi.org/10.1080/10494820.2016.1143844

Ültanir, E. (2012). An epistemological glance at the constructivist approach: Constructivist learning in Dewey, Piaget, and Montessori. International Journal of Instruction, 5, 195-212. Retrieved from ERIC http://files.eric.ed.gov/fulltext/ED533786.pdf

U.S. Department of Education, Office of Educational Technology. (2017). Reimagining the role of technology in education: 2017 National Education Technology Plan update. Retrieved from https://tech.ed.gov/files/2017/01/NETP17.pdf

Yin, R. K. (2009). Case study research: Design and methods (4th ed.). Thousand Oaks, CA: SAGE Publications, Inc. 